\section{Iconic war imagery}

Don McCullin supporting the Freedom of the Press: 100 Photographs, edited by JeanFrançois Julliard. Paris, Reporters sans Frontières, 2009, 144 pp. ISBN 2915536783

$\mathrm{T}$ HE PARIS-based global media freedom group Reporters sans Frontières has carved out an innovative niche for its brand of fund-raising books in defence of the endangered journalist species. The latest addition is another fine collector's item-100 iconic war and social disorder imagery from British photojournalist Don McCullin.

His Sleeping with Ghosts collection (1995), a retrospective of his war photography, particularly struck a chord with me. And this RSF collection of some of his most famous photographs (and many lesser known ones) is just as evocative, at times chilling, filled with anguish and suffering, or just disturbingly reflective.

Having borne witness for more than four decades of the most shattering conflicts of our times, including the Vietnam War, McCullin shares an integral part of the history of photography alongside Magnum legends such as Robert Capa and HenriCartier-Bresson, as well as Gamma's Gilles Caron, his friend and rival.

His observation through the lens

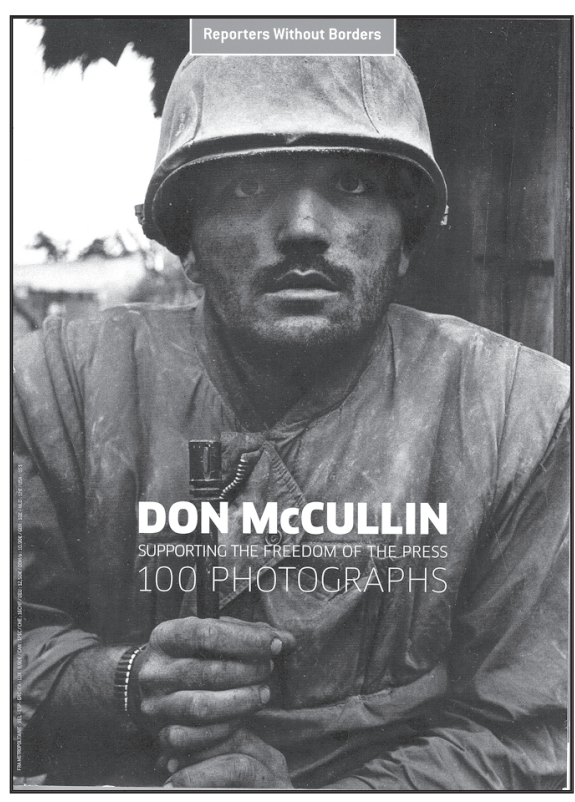

has recorded with empathy, flair and compassion moments of anger and despair, but also unspeakable cruelty inflicted by mankind on their fellows. As Contact Press Images president Robert Pledge notes in one of the introductory passages about the selftaught photographer:

A gaze charged with disbelief, compassion, and solidarity with the weakest, the destitute, the outcast and victims of unacceptable circumstance. Cyprus divided, Congo lacerated, Vietnam bombarded, the Middle East torn, Biafra starving, Cambodia murdered, Salvador in uprising, Northern Ireland in revolt, Iraq tortured, Darfur razed. (p. 11) 
While the ghosts from conflict zones may be prolific and haunting, McCullin has not only photographed warfare, inhumanity and injustice. During his downtime periods from conflict assignments, he has also taken remarkable pictures mirroring life in his native Britain and many global outposts. His photography includes topics as wide-ranging as the $1950 \mathrm{~s}$ teddy boys in his own neighbourhood-London's Finsbury Park; the Beatles; painter Francis Bacon; and the steelworks of West Hartlepool. Further afield, he has documented Indian pilgrimages along the banks of the Ganges, lost tribes in southern Ethiopia, and traces of the Roman Empire around the Mediterranean and social realism in Papua New Guinea. All his images used in this book were donated to support RSF.

Now McCullin is dedicated to seeking an elusive peace, perhaps so poignantly portrayed in a study of AIDS orphans in a schoolroom in Kitwe, Zambia. The innocent children stare questioningly out of one of the closing pages as part of a section on the social ravages of the virus in southern Africa. - Dr David Robie, director of the Pacific Media Centre.

\section{Reference}

McCullin, D. (1995). Sleeping with ghosts: A life's work in photography. London: Vintage.

\section{Short courses: Update your writing and media skills before 2010}

The Australian Centre for Independent Journalism at the University of Technology, Sydney offers professional handson short courses in journalism and the media.

Courses are delivered at the UTS City Campus. They can be tailored to meet organisational requirements and can be delivered externally in Australia and elsewhere.

Courses starting soon include Subediting, Writing for the web, Food writing, Photojournalism, Travel Journalism, Investigative Research Skills, Shorthand, Voice production for broadcast and online journalism, freelancing in the media and video journalism.

For more information, contact Tameera Kemp:

(+61 2) 95142488 or acij@uts.edu.au 